\title{
Meer is beter
}

\section{Marc Wouters}

Het onderwijs moet beter en selectie aan de poort is in de recente plannen van staatssecretaris Zijlstra een wezenlijk element. Selectie aan de poort gebeurt in het Nederlands hoger onderwijs al bij postdoctorale RA- en RC-opleidingen en bij prestigieuze hbo-opleidingen zoals de Design Academy, toneelscholen, en conservatoria. Ook wordt geselecteerd bij de toelating tot universitaire masteropleidingen, vooral als studenten van andere opleidingen, vanuit het hbo of uit het buitenland komen. Maar nu gaat het specifiek om selectie van scholieren bij toelating tot de universitaire bacheloropleidingen.

Scholieren en studenten moeten harder gaan werken en de 'zesjescultuur' moet wijken. Daar is wel wat voor te zeggen, maar ik zou het in deze column willen opnemen voor de scholieren en studenten. Scholen en universiteiten werken nu volgens het motto 'meer is beter' en dan passen de scholieren en studenten zich aan. Ze zijn echt niet substantieel lui, maar die indruk wordt weleens gewekt. Bovendien zou ik, kijkend naar het buitenland, een interessant aspect willen noemen van selectie aan de poort dat nog weinig naar voren komt: marktwerking en reputatie.

Zou er echt zoveel veranderen als er selectie aan de poort wordt toegepast? Scholieren weten nu dat de cijfers voor het eindexamen er niet toe doen, behalve als je een studie wilt doen waarvoor wordt geloot. Dan geven hogere cijfers een grotere kans om ingeloot te worden en met een 8 gemiddeld hoef je sowieso niet met de loting mee te doen. Als cijfers er voortaan wel toe doen, kan dat tot harder werken aanzetten. Maar het is te eenzijdig om alleen deze oorzaak voor de zesjescultuur te noemen. Ik zie dat middelbare scholen ook heel wat te verbeteren hebben. Scholen horen vaak bij grote, overkoepelende onderwijsorganisaties: 'meer is beter'. Besturen en directies vormen een bovenlaag die vaak ver afstaat van het werk in de klas. Deze bestuurders en managers hebben weinig aandacht voor het ambacht van de docent, maar veel aandacht voor competentiegericht leren en natuurlijk voor spectaculaire gebouwen.
Docenten moeten roeien met de riemen die ze hebben: grote klassen, ongeschikte gebouwen en dolgedraaide onderwijsvernieuwingen. Als gevolg daarvan vinden ook zij een 7 al een topcijfer en niet willen blijven zitten is al ambitieus. Het wemelt van de zelfstudie-uren (lees: de kinderen worden aan het lot overgelaten) en het gemaakt hebben van huiswerk wordt nauwelijks gecontroleerd. Het is echt niet zo dat scholen de lat hoog leggen en die vervelende pubers niet willen. Welnee, ze bevestigen elkaar in het idee dat middelmatig goed genoeg is.

Oké, stel dat op middelbare scholen de leerlingen en de docenten werken aan een hoger niveau. Wat gaat er dan op de universiteiten gebeuren? Door de manier van bekostiging en het overheidsbeleid dat is gericht op vergroting van het deel van de bevolking dat hoger onderwijs heeft gevolgd, is meer beter. Universiteiten en hogescholen geven veel geld uit aan werving van studenten en laten het heel graag weten als het aantal eerstejaars is gestegen. Nooit lees je over het niveau van de geworven studenten. Echter, minder maar beter zou bij selectie aan de poort het doel moeten zijn. Stel dat bij een opleiding nu driehonderd eerstejaars zich aanmelden die toelaatbaar zijn. Wat zou de reden kunnen zijn voor die universiteit om niet alle driehonderd aanmelders toe te laten? Immers: meer is beter. Ik zie dit nog niet zo gemakkelijk veranderen.

Oké, stel dat universiteiten toch minder studenten toelaten. Wordt het onderwijs dan uitdagender, kleinschaliger en intensiever, zoals in de huidige plannen de bedoeling is? Eerlijk gezegd zie ik niet veel redenen waarom het onderwijs niet nu al uitdagender, kleinschaliger en intensiever zou kunnen zijn. Universiteiten zouden het onderwijs efficiënter kunnen organiseren, minder geld kunnen besteden aan allerlei overheadactiviteiten, meer belang hechten aan echt goed onderwijs en ervoor zorgen dat docenten er meer werk van maken. Dat gebeurt naar mijn mening nu onvoldoende en ik weet niet waarom dat zou verbeteren als gevolg van selectie aan de poort. Natuurlijk, ik snap best dat je met 
minder studenten gemakkelijker het onderwijs kunt verbeteren. Mijn punt is: ik zie nu beperkte ambitie en een beperkt organisatievermogen bij universiteiten om het onderwijs zoveel als mogelijk is te verbeteren binnen de huidige randvoorwaarden. Het is helemaal niet slecht, maar zolang er geen grote problemen zijn worden docenten niet aangespoord of aangemoedigd het onderwijs heel goed te maken. Het is echt niet zo dat de universiteiten er nu alles aan doen en het onderwijs tiptop is, en de enige mogelijkheid om het NOG beter te maken is selectie aan de poort; er zit niets anders op. Onzin, zolang er nog studies zijn met minder dan tien contacturen per week, zijn er nog mogelijkheden om zonder extra bekostiging en zonder selectie aan de poort het onderwijs te verbeteren.

Oké, stel dat selectie aan de poort wel leidt tot beter onderwijs. Wat kunnen we van ervaringen in het buitenland leren? Ik wil wijzen op een effect waarover ik nog weinig heb gelezen: dit creëert een markt die reputaties zichtbaar maakt. Sommige universiteiten zullen voor een bepaalde opleiding honderden of zelfs duizenden aanvragen krijgen voor tientallen plaatsen, terwijl andere universiteiten voor diezelfde opleiding tientallen aanvragen krijgen voor tientallen plaatsen. Het lijkt me duidelijk dat een opleiding die heel selectief kan zijn, gemiddeld betere studenten heeft. Dat zullen werkgevers ook zien en de reputatie van de opleiding kan verder stijgen. Het zal ook kunnen bijdragen aan de mogelijkheid om betere docenten aan te trekken, enzovoort. In de huidige plannen krijgen universiteiten de mogelijkheid meer differentiatie in collegegelden aan te brengen, en ook de overheid is van plan de bekostiging aan te passen en meer te kijken naar kwaliteit van onderwijs in plaats van alleen naar volume.

$\mathrm{Nu}$ de laatste vraag: hoe zou de overheid de kwaliteit van onderwijs kunnen vaststellen als basis voor bekostiging? $\mathrm{Er}$ is al veel ervaring met beoordeling van onderwijs in verband met accreditaties. Ik zou er nog iets aan toe willen voegen, omdat in dat soort accreditatiebeoordelingen het accent wel erg ligt op de vraag 'hoe processen geborgd zijn'. Dat is vast belangrijk. Daarnaast zou men meer kunnen kijken naar de reputatie en marktpositie van een bepaalde opleiding: Hoe gewild is een opleiding op de markt voor talent onder scholieren (op basis van de verhouding tussen het aantal aanvragers en het aantal studenten voor een opleiding aan een universiteit)? Hoe gewild zijn de afgestudeerden op de arbeidsmarkt (hoe snel hebben studenten een baan op niveau)? Hoe gewild is de opleiding op de arbeidsmarkt voor universitair talent (wat is de kwaliteit en mobiliteit van de mensen die het onderwijs verzorgen)? Een omgeving waar talentvolle mensen graag werken en studeren en die daarbuiten gewild zijn, dat lijkt me de kern van de zaak.
Ik overdrijf natuurlijk. Er is veel te zeggen voor selectie aan de poort. Maar er is nog meer te zeggen voor maatregelen die ertoe leiden dat echt goed (in plaats van goed genoeg) onderwijs op de warme belangstelling kan rekenen van bestuurders die prioriteiten bepalen, van managers die de zaak moeten organiseren en van docenten die het werk moeten doen.

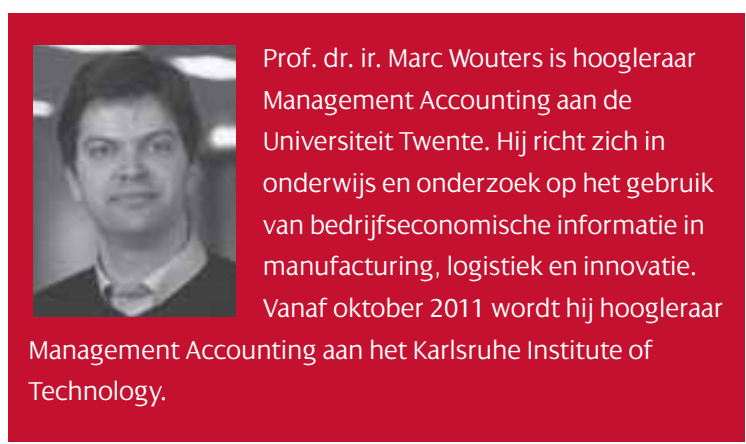

